\title{
Modification of AA Binder Matrix with the Use of PP Fibres - Strength Investigations
}

\section{Szymon Dawczyński and Anna Stokłosa}

Silesian University of Technology, Department of Structural Engineering, 44-100 Gliwice, Poland

\section{Abstract}

The alkali-activated (AA) binders are assumed to be more ecological than ordinary Portland cement (OPC) binders, because of lower energy requisition and lower $\mathrm{CO}_{2}$ emissions during the production processes. The purpose of using polypropylene (PP) fibres in traditional concrete, geopolymers and mortars is to improve strength properties by inhibiting the growth of cracks that usually occur due to shrinkage, as well as improving the mechanical properties. This paper presents laboratory research into the fibre reinforcement impact on the strength properties of an AA binder made of fly ash suspension. In addition to the suspension, which is a waste product from the coal power plant, recycled ground glass and metakaolin were used

Corresponding Author: Szymon Dawczyński szymon.dawczynski@polsl.pl

Received: 20 March 2020 Accepted: 30 April 2020 Published: 13 April 2020

Publishing services provided by Knowledge E

(c) Szymon Dawczyński and Anna Stokłosa. This article is distributed under the terms of the Creative Commons

Attribution License, which permits unrestricted use and redistribution provided that the original author and source are credited.

Selection and Peer-review under the responsibility of the RICON19 - REMINE International Conference Conference Committee.

\section{G OPEN ACCESS} as the precursors. The chemical activator of the geopolimerisation reaction was prepared using sodium hydroxide and sodium silicate. Five different sets of the prism samples $40 \times 40 \times 160 \mathrm{~mm}$ were made (with different PP fibres ratio, from $0 \%$ to $2 \%$ by weight) and then the flexural and compressive strength tests were performed. The addition of polypropylene fibres increased the bending strength, which produced the beneficial effect of reducing crack propagation in cases of tensile stress occurrence.

Keywords: alkali-activated binders, geopolymers, polypropylene fibres, fly ash suspension, bending strength

\section{Introduction}

The main component of a traditional concrete mix is cement, whose production plays an important role in the development of the economy of many countries. Unfortunately, the applied production technology, involving the burning of clinker at high temperatures, is the cause of significant greenhouse gas emissions. The amount of carbon dioxide emitted into the atmosphere by the cement industry accounts for $5 \%$ of global anthropogenic $\mathrm{CO}_{2}$ emissions [1]. It is estimated that 1 ton of cement produced emits 1 ton of carbon dioxide emitted into the atmosphere. This in turn is associated with widespread disapproval and tightening of regulations that regulate this aspect.

One of the already used pro-ecological solutions is to reduce the content of clinker in cement and concrete. This is done using industrial by-products as complementary 
materials in conventional concrete. Such by-products are blast furnace slag, fly ash, natural pozzolana and silica fume. Recent scientific research focuses on the production of concrete without Portland cement. An example of this is alkali-activated concrete or geopolymer, in which an alternative ecological binder is used instead of ordinary Portland cement. By using such binders, with the abovementioned industrial by-products, lower energy costs can be achieved and the amount of carbon dioxide emitted to the atmosphere can be reduced [2].

The general advantage of using polypropylene fibres in traditional concretes, geopolymers and mortars is the elimination of shrinkage cracks, increase of strength, increase of water tightness and frost resistance, and as a result increase of durability of the material. According to [3] polymer fibres are simple or deformed fragments of extruded and cut polymeric material, prepared for homogeneous mixing with a concrete mix or mortar. Polypropylene, like polyethylene, has a partially crystalline structure and is thermoplastic. It shows increased tensile strength, stiffness and a higher melting point. Polypropylene fibres are characterized by flexibility, low density and very good chemical resistance [4].

First of all, the biggest and most desirable advantage of fibre reinforcement dispersed in the form of fibres is limiting the appearance of cracks as a result of shrinkage. The distribution of polypropylene fibres in concrete or mortar creates a spatial mesh that plays the role of micro-reinforcement, which eliminates the need for anti-contraction nets. The reduction of surface and internal cracks limits the penetration of water and harmful liquids, and thus - increases the resistance to corrosion. The tightness of the material also means better frost resistance.

Fibres in concrete significantly improve toughness, which results in better tensile strength, bending strength, fatigue strength and ductility. In addition, they increase the impact strength and resistance to crushing, thus limiting the spreading of the material on the surface as a result of exploitation.

Also, uniform distribution of fibres in the sample eliminates voiding and reduces segregation of ingredients. The fibres cause mutual maintenance of separated fragments of material as a result of the crack and not allowed to disintegrate into parts.

It needs to be highlighted that steel fibres cannot be used in geopolymeric binders (there might occur a chemical reaction between the steel and activator). 


\section{Materials and Samples Preparation}

In general, the alkali-activated materials are obtained by the chemical reaction between an aluminosilicate-rich material and an alkaline solution. At the same time, various types of additives can be used to enhance the material properties, such as strength, workability or to accelerate or delay the setting time.

\subsection{Precursors (solid components)}

As the main solid precursor, it was used the carbon fly ash suspension obtained from the one of the biggest Polish power plants using primarily lignite as a source of energy production. In the chemical composition of fly ashes from this power plant, it can be found an increased as well as differentiated $\mathrm{CaO}$ content. The reason for this is the lake chalk present in the composition of incinerated lignite. Lake chalk consists mainly of calcite $\left(\mathrm{CaCO}_{3}\right)$, which undergoes thermal dissociation in the combustion process. The products of this reaction are lime $(\mathrm{CaO})$ and carbon dioxide $\left(\mathrm{CO}_{2}\right)$. Therefore, these fly ashes are classified as calcium ones [5].

The production technology of the fly ash suspension which was used in this research involves the fusion of fluidized ash suspension and water, followed by milling to obtain a fine-grained material of grey colour. The atomic composition of the fly ash suspension is presented in Table 1, while the oxide composition in Table 2.

TABLE 1: The atomic composition of the fly ash suspension (Authors' own work).

\begin{tabular}{l|l|}
\hline Element & [at. \%] \\
\hline Oxygen & 62.06 \\
\hline Silicon & 14.61 \\
\hline Calcium & 9.28 \\
\hline Aluminium & 8.72 \\
\hline Sulphur & 2.02 \\
\hline Iron & 1.59 \\
\hline Magnesium & 0.85 \\
\hline Titanium & 0.51 \\
\hline Sodium & 0.30 \\
\hline Potassium & 0.08
\end{tabular}

Except the fly ash suspension, also metakaolin and recycled ground glass addition were used for samples preparation. 
TABLE 2: The oxide composition of the fly ash suspension (Authors' own work).

\begin{tabular}{l|c|}
\hline Oxide & [wt. \%] \\
\hline $\mathrm{SiO} 2$ & 39.56 \\
\hline $\mathrm{CaO}$ & 23.45 \\
\hline $\mathrm{Al} 2 \mathrm{O} 3$ & 20.05 \\
$\mathrm{SO} 3$ & 7.27 \\
\hline $\mathrm{Fe} 2 \mathrm{O} 3$ & 5.72 \\
\hline $\mathrm{TiO} 2$ & 1.83 \\
\hline $\mathrm{MgO}$ & 1.54 \\
$\mathrm{Na} 2 \mathrm{O}$ & 0.42 \\
$\mathrm{~K} 2 \mathrm{O}$ & 0.17 \\
\hline
\end{tabular}

The ground glass is a glass powder, which is formed as a result of processing a glass cullet in a special crusher. This product is widely used, starting with the production of household chemicals (washing powders, cleaning pastes), up to industrial production. It is often used in the production of ceramic materials as a filler - thanks to it, the absorbability is reduced and the material gets gloss [6]. The standard oxide composition of the soda-lime glass is presented in Table 3.

TABLE 3: The standard oxide composition of the soda-lime glass (Manufacturer's data).

\begin{tabular}{l|l|}
\hline Oxide & [wt. \%] \\
\hline $\mathrm{SiO} 2$ & 72.60 \\
\hline $\mathrm{Na} 2 \mathrm{O}$ & 13.90 \\
$\mathrm{CaO}$ & 8.40 \\
$\mathrm{MgO}$ & 3.90 \\
\hline $\mathrm{Al} 2 \mathrm{O} 3$ & 1.10 \\
\hline minors & 0.10 \\
\hline
\end{tabular}

In turn, metakaolin is a powdered mineral that arises in the process of kaolin calcination. This material is highly reactive with pozzolanic properties. It contains active particles of aluminium and silicon oxides, which very easily react with free calcium hydroxide $\mathrm{Ca}(\mathrm{OH})_{2}$. As a result of these reactions, the products in the form of released aluminates, silicates and calcium aluminosilicates are similar in structure and composition to the Portland cement hydration products. Applied to concrete mix reduces the porosity of the material, which causes its sealing and reduces water absorption. This positively affects the improvement of properties such as: frost resistance and strength, shrinkage resistance and corrosion resistance to the environmental impact [7]. The metakaolin 
used in this research was a commercial product widely available on the construction market. The oxide composition of the product is shown in Table 4.

TABLE 4: The oxide composition of the metakaolin (Manufacturer's data).

Oxide
$\mathrm{SiO} 2$
$\mathrm{Al} 2 \mathrm{O} 3$
$\mathrm{~K} 2 \mathrm{O}$
$\mathrm{TiO} 2$
$\mathrm{Fe} 2 \mathrm{O} 3$
$\mathrm{CaO}$
$\mathrm{MgO}$
$\mathrm{H} 2 \mathrm{O}$
$\mathrm{Na} 2 \mathrm{O}$
$\mathrm{P} 2 \mathrm{O} 5$
$\mathrm{Cl}$
$\mathrm{MnO}$
$\mathrm{S}$

\begin{tabular}{|c|}
\hline [wt. \%] \\
\hline 53.12 \\
\hline 42.24 \\
\hline 0.73 \\
\hline 0.64 \\
\hline 0.45 \\
\hline 0.44 \\
\hline 0.26 \\
\hline 0.22 \\
\hline 0.09 \\
\hline 0.03 \\
\hline 0.02 \\
\hline 0.01 \\
\hline 0.01 \\
\hline
\end{tabular}

Polypropylene fibres were added to the mixture, which have a special coating that allows easy distribution in it. The exact features of the PP fibres are shown in Table 5

TABLE 5: The properties of the polypropylene fibres (Manufacturer's data).

Feature
type of polymer
class
length
diameter
shape
linear density
tensile strength
strength in relation to thinness
melting temperature
fiber ignition temperature

\begin{tabular}{|c|}
\hline Description \\
polypropylene-ethylene \\
la \\
$12 \mathrm{~mm}$ \\
$34 \mu \mathrm{m}$ \\
short, stitched, rounded, straight \\
$8.3 \mathrm{dtex}$ \\
$3500-3900 \mathrm{~N} / \mathrm{m}^{2}$ \\
$1-28 \mathrm{cN} / \mathrm{tex}$ \\
$165^{\circ} \mathrm{C}$ \\
$365^{\circ} \mathrm{C}$
\end{tabular}

The biggest benefits of using polypropylene fibres as an additive are [8]:

1. reduction of plastic and shrinkage cracking; 
2. increased abrasion resistance;

3. increase of flexural strength;

4. better fire resistance;

5. extended durability;

6. higher level of residual strength;

7. non-magnetic fibres (resistant to rust);

8. chemically inert and alkali resistant.

\subsection{Activators (liquid components)}

An alkaline activator for the production of $A A$ binder samples is the mixtures of aqueous sodium hydroxide solution and the sodium silicate, in the ratio 1:2. $\mathrm{NaOH}$ solution was made with the use of pellets (of molar mass equal $40 \mathrm{~g} / \mathrm{mol}$ ) mixed with distilled water in such a proportion as to obtain the 10-molar solution.

Sodium silicate is a specific chemical and physical mixture, it is colourless and odourless. After the water has evaporated, a thin layer of solidified silicates remains on the surface. The resulting crust is hard, completely watertight and moderately transparent (transparency depends on the type of water glass and the thickness of the layer). When drying, water glass has sticking properties, which is why it is used in various types of adhesives and as a binder for cracked glass or porcelain. Due to the fact that the composition contains only silicates and sodium particles, the dried mass is refractory. This mixture also is used as an addition to mortars. In this research, it was used the sodium silicate of R-145 type and purity higher than $99 \%$. The molar ratio was between 1.6 and 2.6 , while the density was about $1.45 \mathrm{~g} / \mathrm{cm}^{3}$.

\subsection{Mixture}

Percentage share of the solid precursor in the mixture was about: carbon fly ash suspension (80\%), metakaolin (10\%) and ground glass (10\%). The ratio of precursor to activator was equal 1.0, while the ratio of precursor to sodium silicate was equal 1.5. Five sets of samples were prepared for the tests of the fibres impact on strength properties of the AA binder. For each series, the samples were prepared with a different percentage of the fibres (Table 6). 
TABLE 6: The percentage of the fibres used in the mixture (Authors' own work).

\begin{tabular}{l|c|}
\hline The set of samples & $\begin{array}{c}\text { The content of microfibres in } \\
\text { relation to the dry components [\%] }\end{array}$ \\
\hline I & 0.00 \\
\hline II & 0.25 \\
\hline III & 0.50 \\
\hline IV & 1.00 \\
\hline V & 2.00
\end{tabular}

The exact mass of all components was checked with a laboratory scale with accuracy to $1.0 \mathrm{mg}$. All dry and weighted components were mixed together carefully. Then the precursor and activator were combined and mixed. Finally, the PP fibres were added to the mixture.

Fresh geopolymeric mixture with high alkaline conditions may react with steel, that is why it was casted in a mould made of Plexiglas (PMMA). Then the mould was placed in the climatic chamber with constant temperature $60^{\circ} \mathrm{C}$ and humidity $40 \%$. The reaction of geopolimerisation may be faster and influenced positively with a higher temperature of curing [9]. Heat curing usually influences the final mechanical parameters as flexural and compression strength. The exact curing temperature which has the most favourable consequences on the final AA binder strength was the purpose of earlier research [10, 11]. All samples were prepared exactly in the same way and from the same mixture and then placed into the climatic chamber for 24 hours. After the first day of heat curing, samples were left in the room temperature $\left(20^{\circ} \mathrm{C}\right)$ for 27 days.

\section{Results}

The samples were tested after 28 days of curing time. As there is no standard for the methodology of strength test of AA binders, the standard procedure for mortars was used [12]. For performing the strength tests, the PILOT automatic compression-flexural tester was used.

\subsection{Three-point flexural strength test}

The sample during the testing is shown in the Figure 1.

The values of flexural strength of all AA binder samples are shown in Table 7. These values are the average ones from all of the samples with the same ratio of PP fibres. 


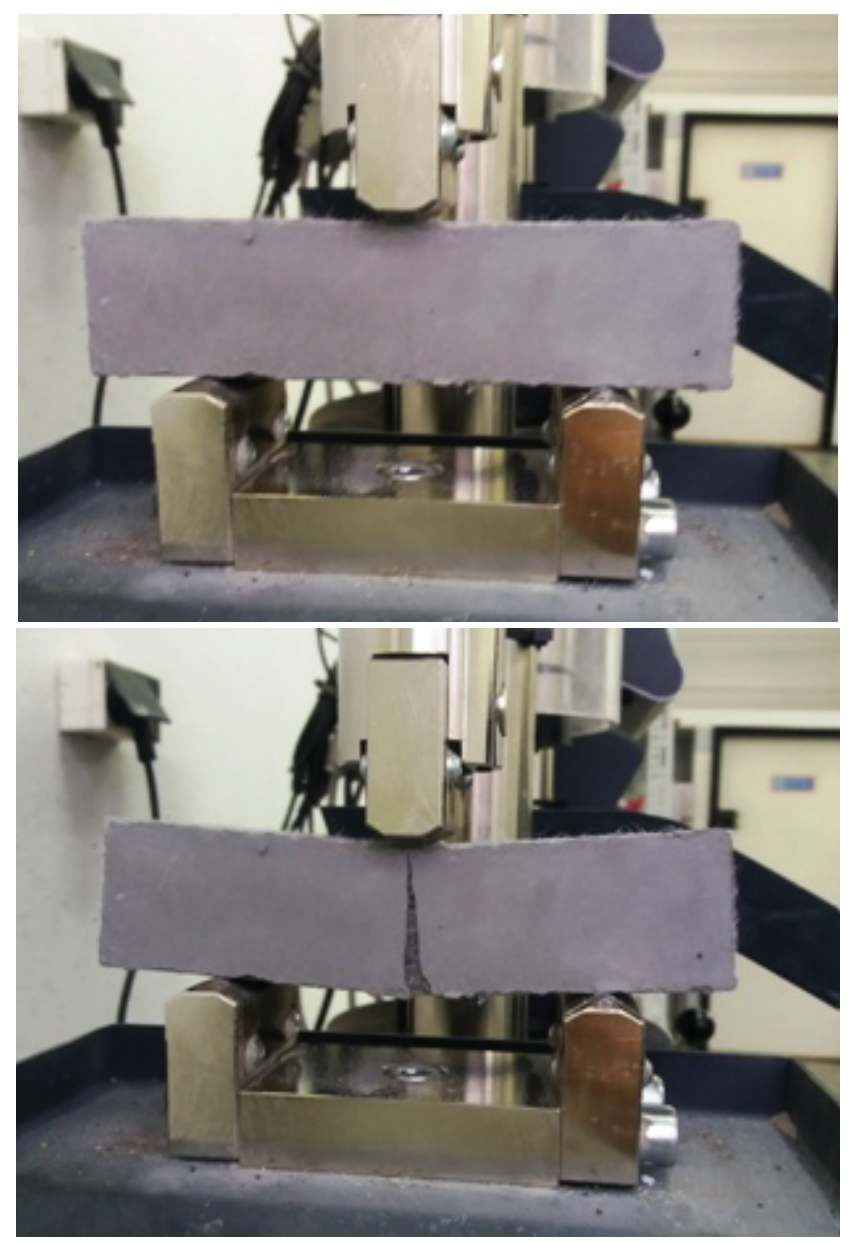

Figure 1: The view of the sample during the bending test (Authors' own work).

Diagram (Figure 2) shows the relationship between the quantity of the fibres and the flexural strength of tested samples.

TABLE 7: The results of three-point bending tests (Authors' own work).

The set of samples
I
III
IV
V

\begin{tabular}{|c|}
\hline $\begin{array}{c}\text { Mean value of destructive } \\
\text { force } F[k N]\end{array}$ \\
\hline 0.855 \\
\hline 1.070 \\
\hline 1.088 \\
\hline 1.199 \\
\hline 1.226 \\
\hline
\end{tabular}

\begin{tabular}{|c|}
\hline Flexural strength $\mathbf{f}_{b}[\mathrm{MPa}]$ \\
\hline 2.00 \\
\hline 2.488 \\
\hline 2.476 \\
\hline 2.809 \\
\hline 2.784 \\
\hline
\end{tabular}

Analysing the results of the flexural test, it can be observed that for the sets with $0.25 \%$ and $0.50 \%$ as well as for the sets with $1.00 \%$ and $2.00 \%$ the results are similar. It might indicate that saturation of the samples with PP fibres occurs gradually and after reaching the specific level, the flexural strength is not increasing. As the flexural strength 


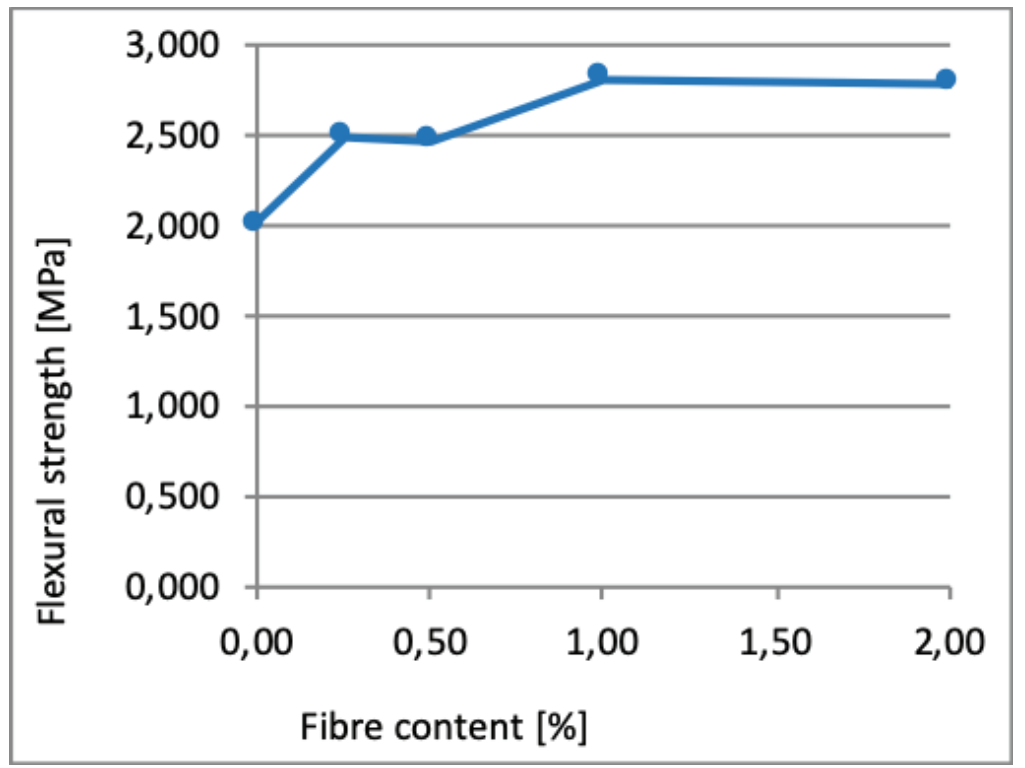

Figure 2: The flexural strength and the fibre content dependence (Authors' own work).

is appointed during three-point strength test (when sample is under tensile), the results also prove, that the fibre reinforcement allows to achieve higher strength values. In this case, the difference between the samples without fibre reinforcement and with fibre reinforcement equals respectively about $24 \%$ (for sets no. II and III) and about $40 \%$ (for sets no. IV and V).

Figure 3 presents the AA binder beam after the destruction. The protruding fragments of polypropylene fibres visible in the place of fracture of the sample prevented the disconnection of both parts of the beam. What interesting, even though the solid matrix was destroyed in the crack plane, the fibres were still connecting the halves of the beam, so the separation was not possible.

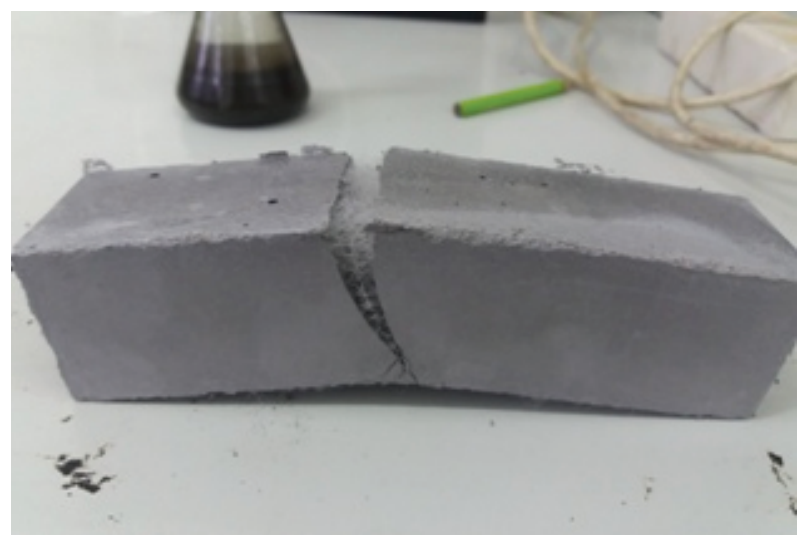

Figure 3: The view of the sample after destruction (Authors' own work). 


\subsection{Compression strength test}

Generally, the fibres are not assumed as the reinforcement in case of compression stress state. However, the halves of the tested beams remain after the three-point flexural strength test, so it was decided to use these elements in compression strength test according to the standard [12]. An example of the sample during the compression strength test is presented in Figure 4.
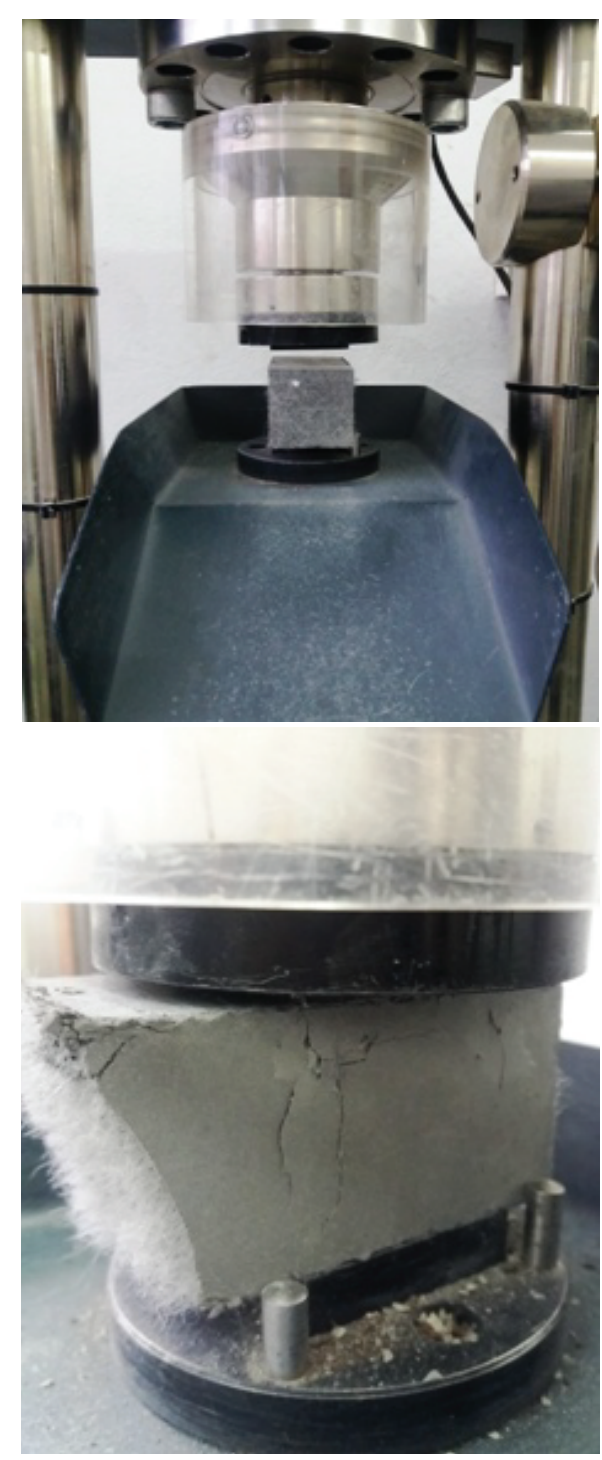

Figure 4: The sample under uniaxial compression strength test (Authors' own work).

The values of compression strength were determined on the basis of the destructive forces' magnitudes. The results of those tests are presented in Table 8. While diagram (Figure 5) shows the relation between compressive strength of the AA binder samples and the content of the PP fibres. 
TABLE 8: The results of uniaxial compression strength tests (Authors' own work).

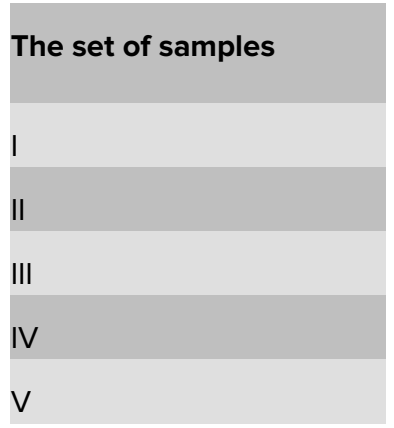

\begin{tabular}{|c|}
$\begin{array}{c}\text { Mean value of destructive } \\
\text { force } P[\mathbf{k N}]\end{array}$ \\
34.89 \\
38.60 \\
37.71 \\
39.10 \\
37.63 \\
\hline
\end{tabular}

\begin{tabular}{|c|}
$\begin{array}{c}\text { Compression strength } \mathbf{f}_{c} \\
{[\mathrm{MPa}]}\end{array}$ \\
\hline 21.80 \\
24.12 \\
\hline 23.57 \\
\hline 24.44 \\
24.14
\end{tabular}

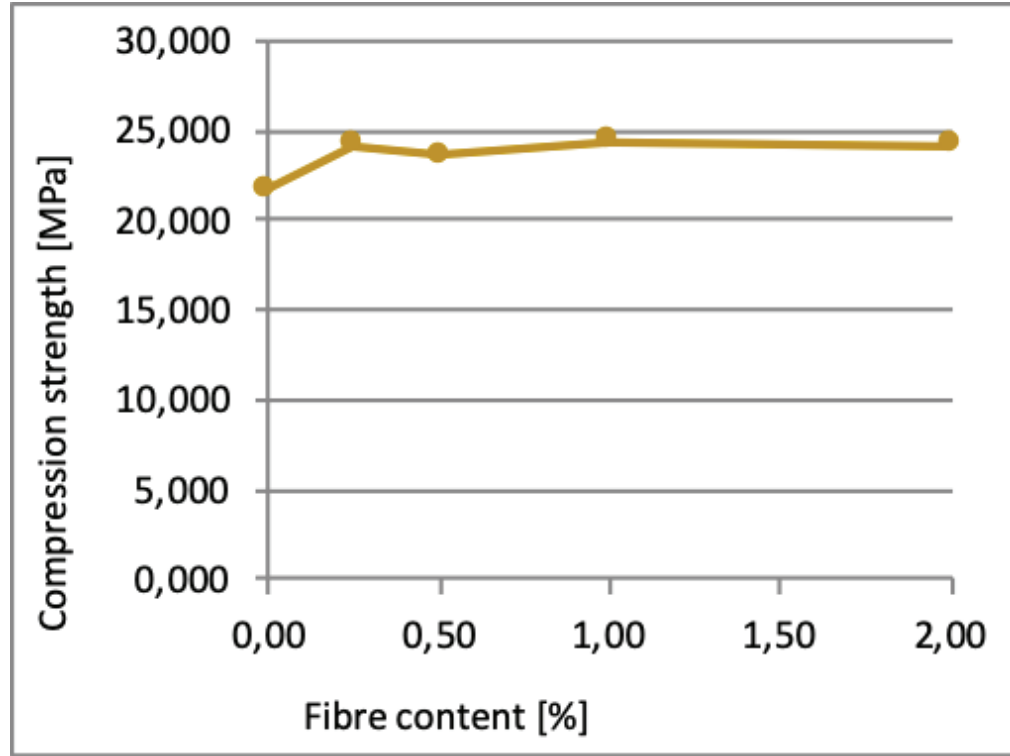

Figure 5: The dependence of the compression strength and the fibre content (Authors' own work).

Analysing the results of the compression tests it is noticeable that the compression strength of AA binder samples with different content of the PP fibres is similar (the difference between the extreme values does not exceed 4\%). On the other hand, the difference between the compression strength of the set without fibre reinforcement and sets of samples with fibre reinforcement is about 8.1-12.1\%. So even though the PP fibre cannot be assumed as a compression reinforcement, but due to compaction of the mixture and additional bonding between the matrix and the fibre, the higher values of the compression strength were achieved in this laboratory research.

\section{Conclusions}

Basing on the results of performed flexural and compression strength tests the following conclusions were drawn: 
1. The use of fiber reinforcement in $A A$ binder samples showed the best results in the flexural strength test, as a general increase in strength was observed with increasing the amount of PP fibers.

2. The most favorable strength test results were obtained in both cases for a series of samples with a one percent content of polypropylene fibers, bending and compression strength values are the highest of all obtained (although the differences between the values for particular sets were not significant).

3. The additive of polypropylene fibers already in the amount of $0.25 \%$ increase the flexural and compression strength of the AA binder samples. The increase for flexural strength is about $24 \%$, and in the case of compression is about $8-10 \%$.

4. A slight decrease in strength in the case of samples with a $2 \%$ fiber content is most probably caused by the saturation of the mixture, which consequently caused its exaggerated compaction and reduced its workability.

5. The PP fibers used in the test, showed the increasing of the crack resistance or even limiting the crack formation. After the bending strength tests (after reaching the flexural strength) the halves of the beams still remained connected with each other only with fibers and they were not easily separated.

When comparing the obtained results with the results for OPC binders presented in the literature, it can be concluded that used polypropylene fibers have a positive effect on the AA binder strength properties.

Summing up, the analysed fly ash suspension-based alkali-activated binder shows the tendency to perform better mechanical properties, while strengthened with PP fibres. As the researches on fibre impact on strength properties of the AA binder are still in the initial stage, so the presented conclusions should be helpful for the next laboratory research.

\section{References}

[1] Uliasz-Bocheńczyk, A. and Mokrzycki, E. (2003). Emisja dwutlenku węgla w przemyśle cementowym (Carbon dioxide emissions in the cement industry), Zeszyt specjalny, Polityka Energetyczna, vol. 6, pp. 367-375.

[2] Prinsse, S. (2017). Alkali-activated concrete: development of material properties (strength and stiffness) and flexural behaviour of reinforced beams over time. Master's thesis, Delft University of Technology. 
[3] PN-EN 14889-2 (2007). Fibres for concrete. Part 2: Polymer fibres. Definitions, specifications and conformity.

[4] Fejdyś, M. and Łandwijt, M. (2010). Włókna techniczne wzmacniajqce materiały kompozytowe (Technical fibres reinforcing composite materials). (Techniczne Wyroby Włókiennicze, Instytut Technologii Bezpieczeństwa MORATEX).

[5] Hycnar, E., Jończyk, M. W. and Ratajczak, T. (2017). Popioły lotne i iły beidellitowe z Bełchatowa jako składniki mieszanin samozestalających się (Fly ash and beidellite clays from Bełchatów as components of self-solidifying mixtures), Zeszyty naukowe, vol.100, pp. 37-48.

[6] ArtGlas Recykling. (2019). Mączka szklana - information material available on the website: http://www.artglas-recykling.pl/maczka-szklana.html

[7] ASTRA. (2019) Astra MK 40 - information material available on the website: http: //www.astra-polska.com/oferta/betony-przemyslowe/astra-mk-40/

[8] Sylan. (2019). Belmix - włókna polipropylenowe do betonów i zapraw (Belmix polypropylene fibres for concretes and mortars) - information material available on the website: https://sylan.pl/index.php?p=oferta

[9] Imbabi, M. S., Carrigan, C. and McKenna, S. (2012). Trends and developments in green cement and concrete technology. International Journal of Sustainable Built Environment, vol. 1, issue 2, pp. 194-216.

[10] Dawczyński, S., Soczyński, M. and Górski, M. (2019). Feasibility and strength properties of the geopolymeric binder made of fly ash suspension. MATEC Web of Conferences, vol. 262, pp. 1-6.

[11] Dawczyński, S., Kajzer, A. and Górski, M. (2018). Investigation on strength development in geopolymer made of power plant fly ash suspension, in RILEM Proceedings PRO 121. (Paris: RILEM Publications), pp. 467-472.

[12] PN-EN 1015-11 (2001). Methods of test for mortar for masonry - Part 11: Determination of flexural and compressive strength of hardened mortar. 